\title{
Leadership of Schools and Teacher Discipline for Student Character Education
}

\author{
Evi Rohyani ${ }^{1 *}$, Nur Ahyani ${ }^{2}$, Nila Kesumawati ${ }^{2}$ \\ ${ }^{I}$ SMA Negeri 2 OKU \\ ${ }^{2}$ Universitas PGRI Palembang \\ *Corresponding author. E-mail: evirohyani27@gmail.com
}

\begin{abstract}
Intellectual intelligence without being followed by good morals and personality is useless. In this digital era, a person's high morale is also one of the keys to success in making connections in the social world. In forming a good character and personality, it cannot be done self-taught, but it needs guidance and direction from others. Character education is education that supports the social, emotional and ethical development of students. The discipline that a person has can be seen from the personality he has. The development of disciplinary values requires practice and habituation that are carried out consistently every day so that it becomes a good character or personality that is embedded in students. Teacher discipline will be emulated by students. So that before instilling character education, students must first improve teacher discipline. The principal as a leader is obliged to improve teacher discipline in order to be able to be a good role model for students. The leadership of the principal must be able to accommodate this.Therefore, a study is needed with the aim of describing the development of school principals, teacher discipline, and describing the obstacles and obstacles in coaching school principals in improving teacher discipline. This research used a qualitative aproach using phenomenological methods. The techniques used in data collection are observation, interview, and documentation. This study's analysis step was carried out in several stages, namely data collection, reduction, data presentation, and conclusions. This study's results are the principal's coaching is carried out by implementing cooperation with all school elements according to their abilities and expertise and the teacher discipline can be seen from attendance using fingerprints and the results of supervision reported in the form of Teacher Performance Appraisal.
\end{abstract}

Keywords: principal development, teacher discipline, character education

\section{INTRODUCTION}

Education is very important for humans. Education is the hope to bring all the goodness to each person. Education is for building intellectual intelligence, but the most important part is developing one's emotional intelligence and character. Humans have a character that in their development must go through a process of education or learning. Education and learning are important processes to ensure development. A person's character according to the norms prevailing in society [1].

Character education is a must in the era of globalization so that bad attitudes and behavior do not easily influence students. Character education is concerned with developing values, morals and good habits, a positive attitude, to form individuals responsible for the actions taken. The education process's success is inseparable from how the planning, implementation, and supporting policies are carried out continuously. Since education is the basic capital of development, every country naturally places it on its main goal. This is also in accordance with the purpose of forming the Unitary State of the Republic of Indonesia, which was finally stated in the preamble to the 1945 Constitution of the fourth paragraph, among which is "To educate the nation's life". Because the founding fathers realized that education was the main means of changing the nation's civilization for the better [1].

The success of a learning process is determined by the factors of the teacher, infrastructure, environment, and course the students themselves, have the willingness or motivation to actively develop their potential. The purpose of education to prepare a generation that is superior with competitiveness and personality or national character can be optimally achieved according to the mandate of the law [1]. 
The purpose of education is to form a generation that completely means to have intellectual intelligence, good attitudes, and the skills needed to live life in society. This is the task of the teacher in carrying out the learning process as part of the educational process to be able to produce learning whose output is a balance of cognitive, affective or attitude and psychomotor achievements. Therefore, in the learning process the obligations and roles of teachers are very vital. The teacher must be able to act as a facilitator and identify all the advantages and disadvantages of the learning models that will be applied so that they actually create an effective learning. Basically, teaching teachers are an effort to create conditions or environmental systems that support and allow the learning process to occur [2].

Creating appropriate conditions or environmental systems for student karate formation is one of the teachers' duties. To form a disciplined character, students need examples and role models. The teacher is the main figure in the learning process who provides examples and role models in the discipline. Discipline is a feeling to obey what he believes through consistent action. The discipline as a character value means that character is built on the values of discipline, and discipline is part of positive character [3]. In practice, a teacher must be able to provide an example to students in disciplines. This is in order to build student disciplinary character and foster responsible character.

The success of education and the manifestation of improving the quality of education in schools are determined by the principal's success in managing the educational staff available at schools. The principal is one of the components of education that is influential in improving teacher performance. The principal is responsible for organizing educational activities, running schools, coaching other educational personnel, as well as maintenance and infrastructure [4]. Good school principal leadership will create a successful school culture that encourages teachers to work with dedication and students to learn without coercion.Teacher performance is a process carried out by all components in schools, both teachers, principals, and students to improve students' quality of learning. Including teacher discipline that needs to be improved in order to build student character. Teacher discipline cannot be separated from the influence of the principal's leadership. Because leadership is a process of influencing, commanding persuasively, setting an example, and guiding others to achieve predetermined goals [5]. It is necessary to provide guided by the principal of teacher discipline in the context of forming student character education.

\section{METHODS}

This research is qualitative research. Qualitative research is an interpretive/constructivist research, where reality is constructed in a context and social life. This study leads to understanding and interpreting meaning according to what is constructed by the subject under study based on their social interactions, not according to the researcher's formula. Researchers make direct contact with subjects in the field in order to gain a holistic understanding, interpretation of meaning, which is contextual. This research was conducted to analyze facts, symptoms, and events that occurred in the field. This study uses a phenomenological research method. Data collection techniques consisted of interviews, observation and documentation. Data analysis techniques consists of data collection, data presentation, data reduction and conclusion or verification.

\section{RESULT AND DISCUSSION}

The results of the analysis and identification of problems in SMAN 2 OKU obtained data that some honorary teachers work part-time so that the teacher's focus is divided into 2 in carrying out their duties. The teacher in delivering the teaching material is not optimal, this can be seen when the teacher does not use teaching aids that can support the learning process. Lack of teacher responsibility in teaching, this can be seen from the frequency of teachers being late into the classroom to teach. Lack of student guidance in the learning process. After identifying the problem, the Principal conducts a coordination meeting with the Deputy Principals, Heads of Laboratories, Head of Libraries, Treasurers, Coordinator of Administration, Coordination of Counseling Guidance to find solutions to existing problems.

Actions that the Head of SMAN 2 OKU has takenthe Head of SMAN 2 OKU has taken have carried out the functions of instruction, consultative, participatory, delegation and control. The instructional function can be seen from holding meetings with related parties to discuss problems related to the 
identification that has been carried out, the consultative function is in the preparation of the RKAS which involves the treasurer and other parties. Participatory function is also carried out by involving all parties in determining the policies to be taken in solving existing problems. The function of delegation is carried out when supervising the principal by giving mandates to senior teachers to conduct classroom supervision. The function of the control is in rewards and punishments for teachers who violate the rules and regulations.

The principal of SMAN 2 OKU has also provided a good example, this is evidenced by the election of him to be the Headmaster of the Provincial Level Outstanding School in 2019. According to Zuryati's [21] statement, leadership is a typical way of behaving from a leader towards his group members. This statement means that the leadership of the principal has a strategic function in the development of teacher performance, without a good example the teacher cannot do their job well and according to the plan expected by the school.

Democracy development is one of the techniques or ways of educating and guiding children, in which parents or educators are open to the demands and opinions expressed by children, then discuss these together [22]. This pattern focuses more on the aspects of education than on the aspects of punishment, parents or educators provide broad rules and provide an explanation of the reasons for giving these punishments and rewards. Democratic parenting is characterized by acceptance, responsiveness, orientation to children's needs accompanied by demands, controls and restrictions. This is in accordance with the guidance carried out by the Principal of SMAN 2 OKU who has provided many opportunities for teachers and administrative staff to express opinions for the progress of the school. The opinions expressed will be accepted to be analyzed and reviewed then discussed together, whether it can be done or not. This makes teachers and staff feel comfortable and protected and appreciated for their coaching.

Teacher performance is obtained from the results of teacher supervision. Teacher supervision is carried out by the Principal, Senior Teachers and Deputy Principals. The results of supervision are displayed in the teacher performance appraisal as evaluation material. Before carrying out his duties, namely supervising teachers and school administrative staff, a supervisor must understand the principles of planning an academic supervision program. The principles of planning for academic supervision that can be prepared according to Mulyadi and Fahriana [23] are 1) objective (what is there); 2) take responsibility; 3) sustainable; 4) based on national education standards; 5) based on the needs and conditions of the school.

The success of the supervision is determined by the supervisor's ability to formulate systematic steps. The steps for supervision are 1) compiling an academic supervision program, in this arrangement, it must be systematic and continuous and involve the teacher; 2) socializing the academic supervision program to teachers; 3) carry out academic supervision; 4) followup results of supervision [24]. Weaknesses or deficiencies of teachers in carrying out learning activities in class can be identified if academic supervision is carried out programmatically and continuously [25].

This performance appraisal is in accordance with the definition of teacher performance. Which means real work results in quality and quantity achieved by a teacher in carrying out their duties. These tasks are in accordance with the responsibilities assigned to him, consisting of compiling learning programs, implementing, learning, implementing evaluation, and evaluation analysis [26]. Teacher performance is a synergistic element that must be developed to produce professional educators who can produce educational processes relevant to the demands of the situation, conditions, and needs of the graduate user community. With the performance of quality teachers, they will be able to produce quality human resources, so as to improve the quality of schools. High teacher performance cannot be achieved if it is not accompanied by a lack of compliance with applicable regulations in carrying out the work. The work discipline of a teacher can be seen from the teacher's compliance with the regulations in force in schools. In other words, it is necessary to have work discipline in a job, which is the will and willingness of the teacher to fulfill and obey the applicable regulations, both written and unwritten. Work discipline is a mental attitude that always obeys all the rules and regulations that have been set for a specific purpose. With good work, discipline, it will further improve teacher performance, which in turn can improve the quality of education. 


\section{CONCLUSION}

The coaching of the Principals of SMAN 2 OKU is carried out by implementing several things, namely a) building cooperation and coordination between Deputy Principals, Administrative Coordinators and members by dividing the Principal's work program according to their respective main duties and functions; b) The principal involves all elements of the school according to their abilities and expertise.Teacher discipline at SMAN 2 OKU seen from attendance using a fingerprint. The duties and responsibilities of the supervision results are reported in the form of Teacher Performance Appraisal. Barriers and obstacles in coaching school principals to improve the work discipline of teachers of SMAN 2 OKU, namely a) Some honorary teachers work part time so that the focus of the teacher is divided into 2 in carrying out their duties, overcome by reviewing the honorarium and adjusting the teacher's schedule for other jobs; b) Teachers in delivering teaching materials are not optimal, this can be seen when teaching teachers do not use props that can support the learning process, it is overcome by holding instructional media training;c) Lack of teacher responsibility in teaching this is overcome by providing rewards and punishments to teachers to reduce teaching hours and promotion of positions.

\section{REFERENCES}

[1] Wayan E. S. (2020). Pendidikan Karakter pada Pembelajaran Daring. Indonesian Values and Character Education Journal IVCEJ, 3(1), 8 - 19

[2] Sardiman, (2011), Interaksi \& Motivasi Belajar Mengajar, Jakarta: Rajawali Pers

[3] Febriyanto, B., Siti, D.P., Putri, A.R., \& Intan, E.M. (2020), Pendidikan Karakter Dan Nilai Kedisiplinan Peserta Didik Di Sekolah, Jurnal Elementaria Edukasia, 3(1), 75-81

[4] Mulyasa, E., (2014), Pengembangan dan Implementasi Kurikulum 2013. Bandung: PT Remaja Rosdakarya

[5] Sagala, S. (2011). Konsep dan Makna Pembelajaran. Bandung: CV. Alfabeta.

[6] Santika, I. G. N., Kartika, I. M., \& Wahyuni, N. W. R., (2019), Pendidikan Karakter: Studi Kasus Peranan Keluarga Terhadap Pembentukan Karakter Anak Ibu Sunah Di Tanjung Benoa. Widya Accarya. 10 (1), 54-66
[7] Pusat Kurikulum, (2009). Pengembangan dan Pendidikan Budaya dan Karakter Bangsa: Pedoman Sekolah. Jakarta.

[8] Rahman, A., \& Zulkifli, J. (2020), Model Inovasi Pendidikan Karakter di Sekolah, Jurnal Pendidikan Kewarganegaraan, 4 (2), 179 - 191

[9] Chita, A.P.H. (2019). Pendidikan Caracter, AlIrsyad: Jurnal Pendidikan dan Konseling, 9(1), 1-11

[10] Supardi., (2013), Sekolah Efektif Konsep Dasar Dan Peraktiknya. Jakarta: PT Raja Grafindo Persada

[11] Kristiawan, M., \& Rahmat, N. (2018). Peningkatan Profesionalisme Guru Melalui Inovasi Pembelajaran. Jurnal Iqra': Kajian Ilmu Pendidikan, 3(2), 373- 390

[12] Hasanah, M. L., \& Kristiawan, M. (2019). Supervisi Akademik dan Bagaimana Kinerja Guru. Tadbir: Jurnal Studi Manajemen Pendidikan, 3(2), 97-112.

[13] Munandar, A. S. (2011). Psikologi Industri dan Organisasi. Jakarta: Universitas Indonesia (UIPress).

[14] Poerwadarminta. (2013). Perencanaan Pengajaran. Jakarta : Rineka Cipta.

[15] Uno. (2013). Model Pembelajaran Menciptakan Proses Belajar Mengajar yang Kreatif dan Efektif. Jakarta: Bumi Aksara.

[16] Soeharsono, S. (2014), Motivasi dan Disiplin Kerja Karyawan. Jurnal Sumber Daya Manusia

[17] Hariri, H., Ridwan, R., \& Karwan, D. H. (2017). Evolusi Pendekatan Teori Kepemimpinan Menuju Kepemimpinan Efektif.

[18] Anoraga, P. (2013) Psikologi Kepemimpinan, Jakarta: Rineka Cipta

[19] Dubrin A. J. (2015). Leadership (Terjemahan), Edisi Kedua, Prenada Media, Jakarta

[20] Zuryati., Djailani, A. R., \& Usman, N. (2015). Gaya Kepemimpinan Kepala Sekolah Dalam Meningkatkan Kinerja Guru pada SDN 7 Muara Dua Lhoksuemawe. Jurnal Administrasi Pendidikan

[21] Hurlock. (2006) Psikologi Perkembangan Pengantar Dalam Berbagai Bagiannya. Yogyakarta : UGM Press

[22] Mulyadi, \& Fahriana, A. S. (2018). Supervisi Akademik. Malang: Madani. 
[23] Nugraha, M. S. (2015). Pelaksanaan Supervisi Akademik Oleh Kepala Madrasah Aliyah Swasta di Kabupaten Sukabumi Jawa Barat. Jurnal Pendidikan Islam Nadwa. Vol.9,Nomor 1, April 2015.

[24] Alpian., Harapan, E., \& Kesumawati, N. (2020). Pengaruh Supervisi Akademik Dan Kelengkapan Administrasi Mengajar Terhadap Kualitas
Mengajar Guru. Cahaya Pendidikan. 6(1) 25 - 37

[25] Wahyudi, I. (2012). Mengejar Profesionalisme Guru. Jakarta: Prestasi Pustakan Publiser

[26] Purwoko, S. (2018). Pengaruh Kepemimpinan Kepala Sekolah, Komitmen Guru, Disiplin Kerja Guru, dan Budaya Sekolah Terhadap Kinerja Guru SMK. Jurnal Akuntabilitas Manajemen Pendidikan. 6(2): 149 - 162 